\title{
Prevalence of the Settlement of Medical Residences in the State of Tocantins in the Period 2013-2017
}

\author{
Prevalência de Fixação dos Egressos das Residências Médicas no \\ Estado do Tocantins, no Período de 2013-2017
}

\author{
Ana Carolina Batista de Souza Guedes ${ }^{1}$ (i) \\ Fellipe Camargo Ferreira Dias ${ }^{\mathrm{I}}$ iD \\ Neila Barbosa Osório ${ }^{1}$ iD \\ Raquel Prudente de Carvalho Baldaçara ${ }^{\mathrm{I}}$ (D) \\ Virgílio Ribeiro Guedes ${ }^{1}$ (D) \\ Luiz Sinésio Silva Neto ${ }^{\mathrm{I}}$ (D)
}

\section{KEYWORDS}

- Medical Residence.

- Medical Education.

- Postgraduate Education in Medicine.

- Physician.

\section{ABSTRACT}

Introduction: The accomplishment of medical residency $(M R)$ is a type of qualification considered to be the "gold standard" for medical specialization. Understanding whether there is actually greater professional settlement or not stimulated by MR and which factors hinder or contribute to the physician's permanence in that place, are important information for the structuring of medical residency and health system programs. The aim of this study was to evaluate the prevalence of settlement of medical residents who finished the residency training in the state of Tocantins, after the implementation of medical residency programs in the period from 2013 to 2017. Method: This is an observational quantitative research, with a cross-sectional, descriptive and analytical design, using the telematic technique and its own questionnaire, carried out with 44 medical residents that finished the medical residency program in the state of Tocantins. The project was reviewed and approved by the Ethics Committee of the Federal University of Tocantins (UFT) under Opinion number 2.292.540. Results: The prevalence of settlement was $65.9 \%$ of physicians in the state of Tocantins. Most residents were females (59.1\%), with a mean age of $30.8 \pm 3.1$ years, income between 10 and 20 minimum wages (55.8\%) and worked during their residency training (84.1\%). The specialties that showed the highest settlement rates were general surgery and clinical medicine, and among these, the majority works for the private and state health networks. The main reason for not settling in Tocantins was to attend another residency or subspecialty program in another state (64.7\%). Conclusion: The prevalence of medical residents that finished the residency and settled in Tocantins during the analyzed period can be considered high (65.9\%). The fact that most of these individuals are young and female and the reason for not settling in the state are important indicators to be analyzed together with the settlement process and the offering of positions in the specialties available in Tocantins. The results of the study indicated a favorable and strategic perspective of the Medical Residency Programs (MRP) in the medical settlement in Tocantins, which cannot be generalized to the reality of such an unequal health system in the country. A larger public investment in the structuring of health network services is necessary, especially in the municipal network, in the organization of support and socioeconomic development of cities. 


\section{PALAVRAS-CHAVE}

- Residência médica.

- Educação Médica.

- Educação de Pós-Graduação em Medicina. - Médico.

\section{RESUMO}

Introdução: A realização de residência médica (RM) é uma vertente de qualificação considerada "padrão ouro" para a especialização médica. A compreensão dos motivos que levam ou não à maior fixação do profissional estimulado pela RM e a identificação dos fatores que dificultam a permanência do médico no local ou contribuem para isso são importantes informações para a estruturação dos programas de RM e sistema de saúde. O objetivo deste estudo foi avaliar a prevalência de fixação dos egressos no estado do Tocantins, após a implantação das residências médicas no período de 2013 a 2017. Método: Trata-se de uma pesquisa observacional do tipo quantitativo, com delineamento transversal, de caráter descritivo e analítico, com uso da técnica telematizada e questionário próprio, realizada com 44 egressos dos programas de RM no estado do Tocantins. O projeto foi revisado e aprovado pelo Comitê de Ética da Universidade Federal do Tocantins (UFT) sob o Parecer $n^{\circ}$ 2.292.540. Resultados: A prevalência de fixação foi de 65,9\% dos médicos no estado do Tocantins. A maioria dos residentes era do sexo feminino (59,1\%), com idade média de 30,8 $+3,1$ anos e renda entre dez e 20 salários mínimos (55,8\%), e trabalhou durante a residência (84,1\%). As especialidades com maior índice de fixação foram as cirurgias geral e médica. No caso desse estudo, a maioria dos participantes atua nas redes privada e estadual. O principal motivo para não fixação no Tocantins foi cursar outra residência ou subespecialidade em outro estado (64,7\%). Conclusão: A prevalência de fixação das RMs no Tocantins no período analisado pode ser considerada alta (65,9\%). O perfil de feminização, o juvenescimento e o motivo da não fixação dos egressos são importantes indicadores para serem analisados em conjunto com o processo de fixação e oferta de vagas nas especialidades disponibilizadas no Tocantins. Os resultados do estudo apontaram uma perspectiva favorável e estratégica dos Programas de Residência Médica (PRM) na fixação de médico no Tocantins, o que não pode ser generalizado para a realidade de um sistema de saúde tão desigual no país. Um maior investimento público na estruturação dos serviços da rede de saúde, em especial na rede municipal, na organização de apoio e no desenvolvimento socioeconômico das cidades é necessário.

Received on 08/09/19

Accepted on 11/26/19

\section{INTRODUCTION}

The society in which we live, as well as medical practice, undergoes constant transformation; thus, even though study and research in medical education is a well-established field, there is a permanent need for further research. In this sense, medical residency (MR) has been the subject of studies $^{1}$. In Brazil, MR was instituted by Decree n. 80.281, of September 5, 1977 , and is considered a postgraduate teaching modality for physicians, as a specialization course. It can be offered by higher education and health institutions, such as hospitals, research centers, institutes and others. To make MR programs available, institutions must be accredited by the National Medical Residency Commission (CNRM, Comissão Nacional de Residência Médica) ${ }^{2}$. These medical education programs are considered to be the "gold standard" of medical specialization.

The context of MRs in Brazil was presented in the Brazilian Medical Demography Census (CDMB, Censo de Demografia Médica do Brasil). Recent data from this report showed that more than a third of Brazilian physicians do not have a specialist's title. However, it should be noted that physicians with a specialist's title totaled more than 280,000 in 2018, and this number has never been so high in the country. Another important issue highlighted in the document is the uneven distribution of openings between regions. The South region has the equivalent of $16 \%$ of the total national MR openings, while the Northeast has $14.2 \%$, the Midwest, $7.2 \%$. The North region has the lowest group of residents, around $4.1 \%$, while the state of Tocantins has $0.4 \%$ of physicians attending MR programs ${ }^{3}$.

The National Support Program for the Training of Board-Certified Physicians in Strategic Areas (Pró-Residência) supported the opening of MR positions in specialties and priority regions defined by managers of the Brazilian Unified Health System (SUS). Therefore, the first Medical Residency Programs (MRPs) were created in the state of Tocantins ${ }^{4}$. Understanding the factors that contribute to both the offer of positions and the filling of openings and the settlement of residents in the territory can provide important indicators for MRPs.

The proportion of settlement at the place where the physicians attended their MR has been the subject of research ${ }^{5,6}$. This increased interest in the topic can be explained by considering that the MRPs were created and supported on the assumption that specialists were more likely to settle in places where they had attended their MR. The CDMB (2013) presented, in a preliminary report, that almost two thirds of the physicians who graduate do not settle at the place where they graduated, and that around one third returns to their city of origin. Settlement is a condition that involves several factors, such as working conditions, gender, salary, city of origin, family, proximity to large urban and economic centers, that is, personal, institutional and urban conditions. However, there is no consensus that the implementation of medical courses (at undergraduate or graduate level) can allocate new professionals to the place where they attended the $\mathrm{MR}^{7}$.

Interestingly, Tocantins was the last Federation Unit to open MRPs. Within only a few years of creation of these programs in the state, there is little research aiming to demonstrate the association between the offer of MR programs and the settlement of specialists in a certain territory. Moreover, it is of the utmost importance and urgency to evaluate the impact of the implementation of new residency programs in priority regions, to answer the question whether there is really higher professional settlement or not, stimulated by this type of training, and whether there 
are factors that hinder it .

Therefore, the study aims to assess the prevalence of the settlement of medical residents that attended the MRPs in the state of Tocantins, from 2013 to 2017.

\section{MATERIAL AND METHODS}

A quantitative research was carried out, with a cross-sectional design, using as a sample the medical residents that attended the MRPs in the state of Tocantins, accredited by the National Medical Residency Commission (CNRM) between the years 2013 to 2017. The project was reviewed and approved by the Ethics Committee of the Federal University of Tocantins (UFT) under protocol number CAAE 73833615.5.0000.5519 and Opinion number 2,292,540.

The target population of the study were residents linked to the following Higher Education Institutions (HEIs): Universidade Federal do Tocantins - UFT (Palmas - TO), Fundação Escola de Saúde Pública de Palmas - FESP (Palmas - TO), Instituto Tocantinense Presidente Antônio Carlos - ITPAC (Porto Nacional - TO), Instituto Tocantinense Presidente Antônio Carlos - ITPAC (Araguaína - TO) and Centro Universitário de Gurupi - UnirG (Gurupi - TO), who attended MR in the period between 2013 and 2017.

The data for the initial contact with the residents were obtained through the MR Commissions (Coremes), with the following information being collected: name, e-mail, telephone, specialty and year of completion. Afterwards, medical residents were contacted from March to April 2018 to answer the questions indexed in an electronic form (Google.Forms).

According to data sent by Coremes, 142 residents completed the MR during the analyzed period. The exclusion criteria were: residents who had outdated information in the registration form that prevented contact with the study individuals.

The sample was recruited in two stages. In the first one, a form was sent by e-mail to all registered residents, advising them on the survey and the deadline for sending the questionnaire (seven days). At this stage, only 29 residents answered the questionnaire. In the second stage, the remaining residents were contacted by instant messaging for smartphones (WhatsApp) and e-mail; however, 52 cases were excluded due to the outdated phone number (without WhatsApp). Of the 61 residents contacted at this stage, only 15 answered the questionnaire.

At the end of the recruitment period, 44 participants were included in the study, of which 29 answered the data collection instrument by contact via email and 15 answered after contact via WhatsApp:

For this study, a digital data collection instrument was adopted, available for free on the Internet. Participants were invited to answer questions indexed in Google electronic form (Google Forms ${ }^{\circ}$ ) allowing the researchers to break with the impositions of time and space for the development of this stage of the research.

The questionnaire was structured containing 20 questions with open and closed questions to obtain the following information: name, age, gender, marital status, city of birth, year of graduation and what higher education institution they had graduated from, where they attended the residency program, in what institution, year of completion of the medical residency, if they worked in the specialty where they graduated at, if they were currently (after graduation) working in the state of Tocantins, what was the reason for not working in the state of Tocantins, if applicable, if they did not work in Tocantins, in what state they worked at, if they worked in any municipal network in the state of Tocantins and in which municipality, if they worked in the state health network, if they worked in the private network of the state of Tocantins, if before or during residency they were already a state employee or worked at some municipal network, if it was necessary to work during the residency to supplement their income and what was the current income in number of minimum wages.

The data were tabulated in Excel spreadsheets and analyzed using the Stata Program version 14.0. For the description of the variables, mean and standard deviation were used for the numbers, whereas absolute and relative frequencies were used for the categorical ones. To test the proportions, the Chi-square test and Fisher's test were used, with a significance level of $5 \%$.

\section{RESULTS}

Among the assessed residents, the mean age was 30.8 years, $59.1 \%$ were females, $47.7 \%$ were married, $47.7 \%$ were single, $55.8 \%$ reported an income between 10 to 20 minimum wages and $37.2 \%$ were born in the state of Tocantins (Table 1). Most residents had finished medical school between 2011 and 2015 (70.4\%), at private universities (80\%). Almost

\begin{tabular}{|c|c|c|}
\hline \multicolumn{3}{|c|}{$\begin{array}{l}\text { Table } 1 \\
\text { Distribution (\%) of medical professionals according to } \\
\text { socioeconomic and demographic characteristics. 2018. }(\mathrm{n}=44)\end{array}$} \\
\hline Characteristics & $\mathbf{n}$ & $\%$ \\
\hline Age (mean \pm standard deviation) & & $30.8 \pm 3.1$ \\
\hline \multicolumn{3}{|l|}{ Gender } \\
\hline Male & 18 & 40.9 \\
\hline Female & 26 & 59.1 \\
\hline \multicolumn{3}{|l|}{ State of birth } \\
\hline Tocantins & 16 & 37.2 \\
\hline Goiás & 8 & 18.6 \\
\hline Pará & 8 & 18.6 \\
\hline São Paulo & 3 & 7.0 \\
\hline Bahia & 3 & 7.0 \\
\hline Maranhão & 2 & 4.7 \\
\hline Rondônia & 1 & 2.3 \\
\hline Acre & 1 & 2.3 \\
\hline Rio Grande do Sul & 1 & 2.3 \\
\hline \multicolumn{3}{|l|}{ Marital status } \\
\hline Single & 21 & 47.7 \\
\hline Married & 21 & 47.7 \\
\hline Divorced & 2 & 4.6 \\
\hline \multicolumn{3}{|l|}{ Income } \\
\hline Up to 10 minimum wages & 10 & 23.3 \\
\hline From 10 to 20 minimum wages & 24 & 55.8 \\
\hline Above 20 minimum wages & 9 & 20.9 \\
\hline Total & 44 & 100.0 \\
\hline
\end{tabular}


all physicians reported having attended medical residency at the Federal University of Tocantins (90.9\%), in a single specialty (90.9\%), and worked during the residency (84.1\%). Among the medical professionals who worked during the residency to supplement their income, 27 (71.0\%) of them were already employees of the municipality or the state.

The medical specialties with the higher number of professionals were: general surgery (36.4\%), clinical medicine $(27.3 \%)$ and pediatrics $(20.5 \%)$ (Figure 1). Most physicians (93.2\%) reported working at the specialty they chose for the MRP. When comparing the specialty according to gender, it was observed that rheumatology and anesthesiology predominated among men, while pediatrics, endocrinology, psychiatry, and family health prevailed among women (Figure 2).

The prevalence of settlement was $65.9 \%$ of the evaluated physicians who remained working in the state of Tocantins. When assessing the profile of residents who settled in Tocantins $(n=29)$, the highest proportions were found among women (69.3\%), with an income of 10 to 20 minimum wages $(75 \%)$, who attended residency at UFT and with a mean age of 31.2 years $(67.5 \%)$ (Table 2). General surgery (43.8\%), Clinical Medicine (41.7\%) and Anesthesiology (33.3\%) were the specialties that had the lowest percentage of settlement. Most physicians work at the state (79.3\%) and private (75.9\%) health network, while less than $40 \%$ work in the municipal network (Figure 3).

Among physicians who did not settle in the state of Tocantins, $64.7 \%$ stated they attended another residency program or subspecialty in another state, $11.8 \%$ reported low remuneration, $11.8 \%$ did it due to family issues and $11.7 \%$ due to lack of work opportunities (Figure 4).

\section{Figure 1}

Distribution (\%) of medical professionals according to medical residency specialties. 2018. $(n=44)$

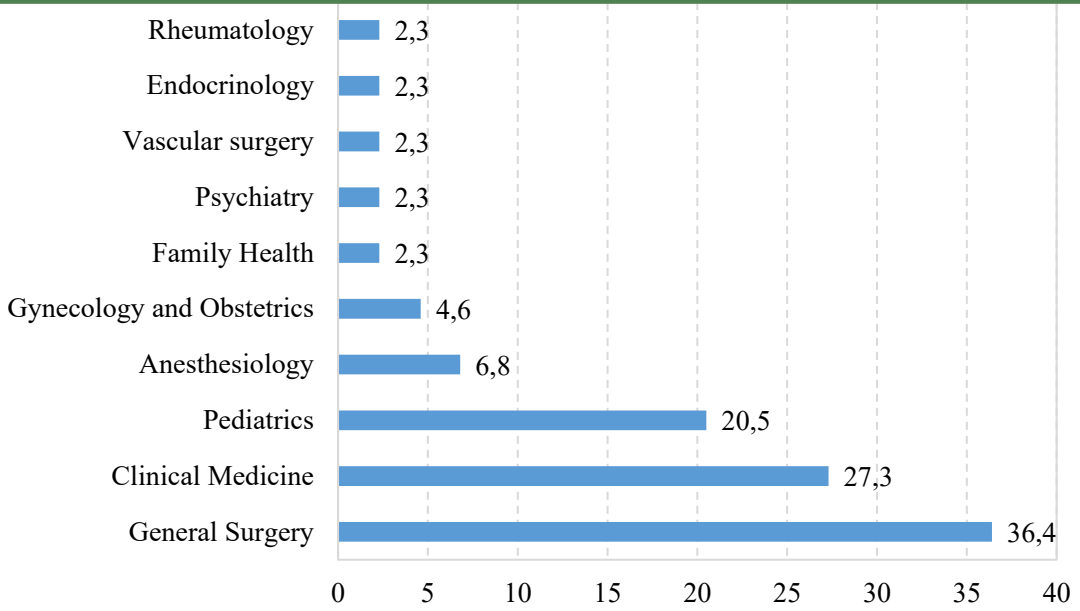

General Surgery
Clinical Medicine

Pediatrics

Anesthesiology

Gynecology and Obstetrics

Family Health

Psychiatry

Endocrinology

Rheumatology

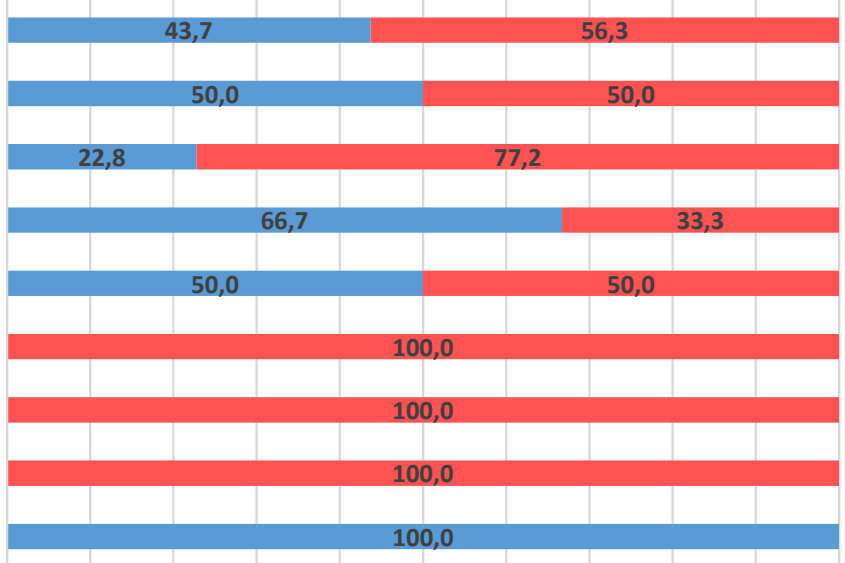

$\begin{array}{lllllllllll}0 \% & 10 \% & 20 \% & 30 \% & 40 \% & 50 \% & 60 \% & 70 \% & 80 \% & 90 \% & 100 \%\end{array}$

- Man woman 


\begin{tabular}{|c|c|c|c|c|c|}
\hline \multicolumn{6}{|c|}{$\begin{array}{l}\text { Distribution (\%) of medical professionals according to } \\
\text { socioeconomic, demographic characteristics and whether or not } \\
\text { they were working in the State of Tocantins. 2018. }(n=44)\end{array}$} \\
\hline \multirow{3}{*}{ Characteristics } & \multicolumn{4}{|c|}{$\begin{array}{l}\text { Physicians working in the } \\
\text { state of Tocantins }\end{array}$} & \multirow{3}{*}{$\mathbf{P}^{*}$} \\
\hline & \multicolumn{2}{|c|}{ No } & \multicolumn{2}{|c|}{ Yes } & \\
\hline & $\mathbf{F}$ & $\%$ & $\mathbf{F}$ & $\%$ & \\
\hline Age (mean \pm standard deviation) & \multicolumn{2}{|c|}{$29.9 \pm 2.3$} & \multicolumn{2}{|c|}{$31.2 \pm 3.3$} & \\
\hline Gender & & & & & 0.576 \\
\hline Male & 7 & 38.9 & 11 & 61.1 & \\
\hline Female & 8 & 30.7 & 18 & 69.3 & \\
\hline Income & & & & & 0.301 \\
\hline Up to 10 minimum wages & 5 & 50.0 & 5 & 50.0 & \\
\hline From 10 to 20 minimum wages & 6 & 25.0 & 18 & 75.0 & \\
\hline Above 20 minimum wages & 4 & 44.4 & 5 & 55.6 & \\
\hline $\begin{array}{l}\text { Institution where they attended } \\
\text { residency }\end{array}$ & & & & & 0.320 \\
\hline UFT & 13 & 32.5 & 27 & 67.5 & \\
\hline ITPAC & 1 & 33.3 & 2 & 66.7 & \\
\hline Unirg & 1 & 100.0 & 0 & 0.0 & \\
\hline
\end{tabular}

\section{DISCUSSION}

Among the main findings of this study, the prevalence of settlement of residents in the state of Tocantins in the analyzed period was $65.9 \%$, and this value can be considered high ${ }^{6}$. In contrast to a previous study that evaluated 37 professionals who attended medical residency programs in the state between 2013-2014, they found a percentage of $29.2 \%(n=7)$ who remained in Tocantins ${ }^{5}$. However, these differences can be explained due to the fact that the analyzed period was different and the growing offer of medical specialization programs, especially in the creation of openings for subspecialization in the following years. The incentive and funding for medical residency in regions and specialties considered priority through the Pro-Residency program by the federal government seems to have contributed to the increase in the number of MR openings in priority regions, and Tocantins is included in this criterion. Another aspect to be considered is that $37.2 \%$ of the residents were born and attended residency in the state, and even though there is no consensus in the literature, the fact of attending medical residency in one's place of birth, in this study, contributed to a higher rate of settlement.

The prevalence of settlement depends on other factors, such as the human development index (HDI) of cities. Tocantins is a state that still offers good quality of life, with lower rates of violence when compared to other states in the Northern region ${ }^{8}$. In particular, the capital city, Palmas, has a good HDI (0.788), considered the best in Tocantins and one of the best in the North region". We emphasize that even with this increasing prevalence of settlement, there is a need for expansion with investments in MR programs in Tocantins.

There were no settlement differences between the genders. This issue

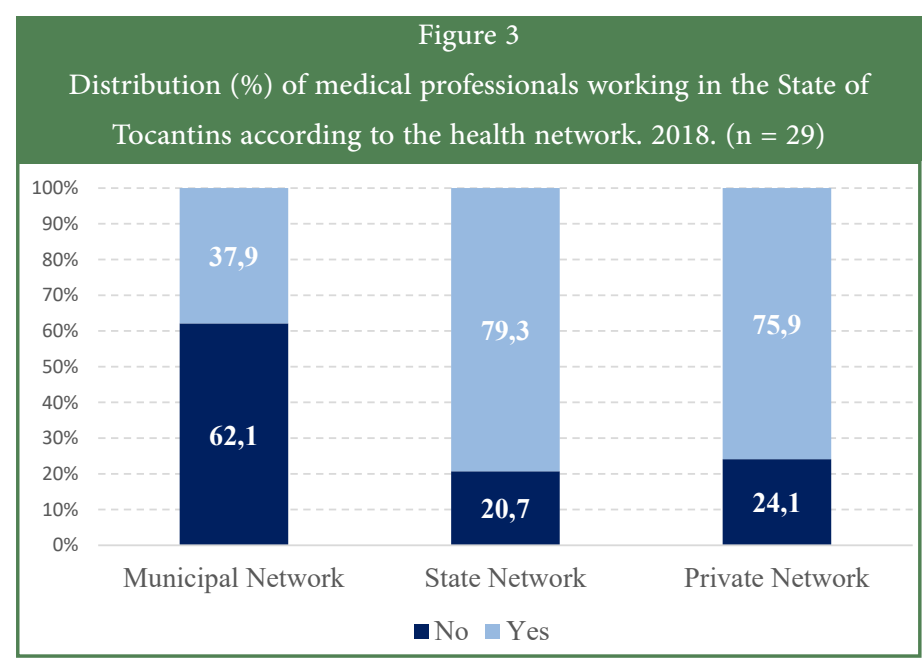

\begin{tabular}{l} 
Figure 4 \\
$\begin{array}{l}\text { Distribution (\%) of medical professionals according to the reasons } \\
\text { they did not remain in the State of Tocantins. 2018. ( } \mathrm{n}=17)\end{array}$ \\
\hline - Attending another residency or subspecialty in another state \\
- Low remuneration \\
- Family issues \\
- Lack of work opportunities
\end{tabular}

does not seem to be well defined in the literature. A study carried out by Ney \& Rodrigues ${ }^{7}$ identified $83.3 \%$ of men and $76 \%$ of women residing in the state of São Paulo, pointing to a discreet trend towards a higher rate of settlement among men in the place where they attended residency. However, Scheffer \& Cassenote ${ }^{3}$ demonstrated that women have a lower tendency to emigrate than men, that is, they settle more frequently where they attended the MR.

In the present study, it was found that the main institution offering medical residency in the state of Tocantins is the Federal University of Tocantins - UFT (a public institution), while the majority of undergraduate training took place in private schools. The importance of UFT as a center of specialized medical training is highlighted, which allowed more than $60 \%$ of these specialists to settle in Tocantins. This scenario is similar to those of other studies that reinforced the role of public funding in medical residency programs. The authors emphasize that there is no specific information on private sector funding, but the majority of openings in private institutions are funded by the government ${ }^{10,11}$.

Our data corroborate the young and female profile of medical professionals ${ }^{3}$, as a prevalence of $59.1 \%$ of women and a mean age of 30.8 years was demonstrated. The number of male physicians in Brazil 
is higher than that of women, respectively $54.4 \%$ and $45.6 \%$. However, this difference is being reduced every year and indicates an increasing feminization of the medical profession in the country ${ }^{3}$. This process in Medicine is accompanied by the fact that medical professionals are increasingly younger. However, these processes must be analyzed considering differences between the studied population.

Due to the feminization of Medicine, some specialties concentrated greater proportions of women in this study, as evidenced in pediatrics $77.2 \%$, psychiatry $100 \%$, endocrinology $100 \%$ and family health with $100 \%$ of women. These data differ in relation to psychiatry, since the highest proportion of psychiatrists in Brazil was male ${ }^{3}$. Another area where the male presence stood out was rheumatology, with $100 \%$, and anesthesiology, with $66.7 \%$.

During medical residency, most of the assessed individuals (84.1\%) worked to supplement their income, with the highest proportions of physicians working in the state of Tocantins reporting income greater than 10 minimum wages. Residency is not mandatory for practicing medicine in the country, so some physicians start working immediately after the end of six years of medical school. For Santos ${ }^{12}$, the newly graduated physician usually (but not exclusively) works in emergency services, such as the Mobile Emergency Care Service (SAMU, Serviço de Atendimento Móvel de Urgência) or as physicians in the Family Health Strategy in government programs. Both are public jobs with their own training programs. Most, however, want to complete the training and become a specialist through the medical residency model.

The percentage of residents was higher in General Surgery with $36.4 \%$, Clinical Medicine with 27.3\%, Pediatrics 20.5\% and Anesthesiology with $6.8 \%$. However, when assessing the prevalence of settlement of these residency programs, we observed that three (General Surgery, Clinical Medicine and Anesthesiology) do not have a $100 \%$ prevalence of settlement like the others analyzed; even so, they still have a prevalence of settlement above $30 \%{ }^{6}$. In Brazil, four specialties concentrate almost $40 \%$ of specialists. Clinical Medicine, $11.2 \%$; Pediatrics, $10.3 \%$; General Surgery 8.9\%; and Gynecology and Obstetrics, $8 \%$. The offer and filling of MR openings in specialties are related to the distribution of specialist physicians already with a title and working in their specialty ${ }^{3}$. It is important to highlight that the availability of specialties by the institutions is the responsibility of the Coremes. The Coreme must follow the rules of the institution's statute and always respect the legislation, rules and resolutions of the CNRM, drawing up the norms/regulations ${ }^{12}$.

Of the individuals who worked in Tocantins, the majority were linked to the private and state health network. According to Baldaçara \& Baldaçara ${ }^{5}$, the main reason for not working in the municipal health services was probably due to low pay and poor work structure. A study carried out by Mello et al. ${ }^{13}$, reinforces the factors that contribute to situations unfavorable to physicians' settlement in the municipalities, such as, high turnover of physicians and nurses, precarious work bonds and lack of career plans, low training, overload and excessive interference from local politics.

The main reason for not settling in Tocantins was to attend another residency program or subspecialty in another state (64.7\%); these data corroborates a study by Machado \& Pinto ${ }^{14}$, where they highlighted that "when the doctor attends a second or third residency, these are usually in surgical specialties, or in specialized areas in the field of Clinical Medicine".
In this context, in a study carried out by Ney \& Rodrigues ${ }^{7}$ analyzed 129 residents who attended MR in the state of São Paulo in the specialty of Family and Community Medicine and observed that the majority of the participants (99.2\%) continued their academic training after completing the residency, with $57 \%$ having completed a lato sensu postgraduate course, $31.8 \%$ a stricto sensu course and $10.1 \%$ having attended another MR. This search for continuous specialized training seems to be a reality for the professionals who attended the MR in Tocantins. These data are important indicators for the Coremes to consider when offering new openings for subspecialties.

\section{Limitations}

One of the limitations of this study refers to the recruitment of participants, since many of the contact data were outdated, leading to a significant loss of contact with these professionals, in addition to the low response rate of physicians with updated registration data. However, the study is relevant because it demonstrates the profile of the professionals and the identification of the reasons why they did not settle there within a period of 5 years.

\section{CONCLUSION}

In the present study, a high prevalence of settlement among professionals who attended MR in Tocantins was evidenced in the analyzed period. The profile of this professional is highlighted by a higher number of female and young individuals and the fact that the vast majority of them worked during the MR to supplement their income. In the studied population, General Surgery, Clinical Medicine and Pediatrics were the specialties most often chosen by the settled physicians.

It was possible to verify that the non-settlement of the physicians was motivated by the search in attending another residency or subspecialty in another state. Moreover, we highlight that the private and state health networks are the places that have the largest number of professionals who finished the MR, and that the municipal health services have a low contribution to the settlement of the analyzed population. In this context, there is an urgent need for structural policies for better settlement in the municipal public service.

The results of the study showed a favorable and strategic perspective of the Medical Residency Programs (MRPs) for the physicians' settlement in Tocantins, which cannot be generalized to the reality of such an unequal health system in the country. Greater public investment aimed at structuring health network services, especially in the municipal network, in the organization of support and socioeconomic development of cities, is necessary.

Finally, we believe that future studies with a longitudinal design, can contribute to a better understanding of the impact of MR and thus, support the training policies of MRPs.

\section{REFERENCES}

1. Oliveira NMF, Barreto B, Furlaneto IP, Borges Neto FC. Conhecimento de alunos de Medicina do Centro Universitário do Estado do Pará sobre a residência médica. Rev. bras. educ. méd. 2019;43(1):32-8.

2. Padilha RQ. Gestão de Programas de Residência Médica no SUS: caderno do curso 2014 / Roberto de Queiroz Padilha. São Paulo: Instituto Sírio-Libanês de Ensino e Pesquisa, Ministério da Saúde; 2014.

3. Scheffer MC, Cassenote AJF. Demografia médica no Brasil. São Paulo: FMUSP, CFM, Cremesp; 2018. 
4. Brasil. Portaria Interministerial $\mathrm{n}^{\circ} 1001$, de 22 outubro de 2009 . Institui o Programa Nacional de Apoio à Formação de Médicos Especialistas em Áreas Estratégicas - Pró-Residência. Diário Oficial da União 23 out 2009; Seção 1, p. 9.

5. Baldaçara L, Baldaçara RPC. Proportion of doctors who stayed in the state of Tocantins after finishing medical residency: preliminary results from a cross-sectional study. São Paulo med. j. 2018;136(1):115 [aceso em 12 set 2018] 1-5. Disponível em: http://www.scielo.br/ pdf/spmj/v136n1/1806-9460-spmj-1516-3180-2016-0340280117.pdf.

6. Nunes MT, Michel JLM, Brenelli SL, Haddad AE, Mafra D, Ribeiro ECO. Distribuição das vagas de residência médica e de médicos nas regiões do país. Cadernos ABEM 2011;7: 28-34.

7. Ney MS, Rodrigues PHA. Fatores críticos para a fixação do médico na Estratégia Saúde da Família. Physis (Rio J.) 2012;22(4):1293-311 [acesso em 12 ago 2017]. Disponível em: http://www.scielo.br/pdf/ physis/v22n4/a03v22n4.pdf.

8. Cerqueira DC, Lima RSD, Bueno S, Neme C, Ferreira H, Coelho D et al. Atlas da violência 2018. Rio de Janeiro: Ipea, FBSP; 2018

9. Instituto Brasileiro de Geografia e Estatística. Censo demográfico de 2010. Rio de Janeiro: IBGE; 2010.

10. Michel JLM, Lopes Junior A, Santos RA, Oliveira RAB, Rebelatto JR, Nunes MPT. Residência Médica no Brasil: panorama geral das especialidades e áreas de atuação reconhecidas, situação de financiamento público e de vagas oferecidas. Cadernos ABEM 2011;7:13-27.

11. Universidade Federal de Minas Gerais, Faculdade de Medicina, Núcleo de Educação em Saúde Coletiva. Avaliação nacional da demanda de médicos especialistas percebida pelos gestores de saúde. Belo Horizonte: UFMG; 2009.

12. Santos RA. A creditação e avaliação de programas de residência médica: concepção internacional e proposta de um modelo nacional. São Paulo. Tese [Doutorado] - Universidade de São Paulo; 2016.
13. Mello GA, Mattos ATR, Souto BFA, Fontanella BJB, Demarzo MMP. Médico de família: ser ou não ser? Dilemas envolvidos na escolha desta carreira. Rev. bras. educ. méd. 2009;33:475-82 [acesso em 15 nov 2017]. Disponível em: http://www.scielo.br/pdf/rbem/v33n3/17.pdf.

14. Machado MH, Pinto LF. Médicos residentes no Brasil. In: XXXI Congresso Nacional dos Médicos Residentes; 1996; Natal, Brasil. Natal; 1996

\section{AUTHORS' CONTRIBUTIONS}

Ana Carolina Batista de Souza Guedes: creator of the study, responsible for data collection and writing of the manuscript;

Fellipe Camargo Ferreira Dias: collaborator in the literature review, data collection, writing and revision of the manuscript;

Neila Barbosa Osório: collaborated in the literature review, writing and revision of the manuscript;

Raquel Prudente Baldaçara: contribution to the study design, analysis of the writing and final revision of the text;

Virgílio Ribeiro Guedes: collaborator in the literature review, writing and revision of the manuscript;

Luiz Sinésio Silva Neto: supervising researcher, participated in all stages of the research, from its creation, execution to writing of reports, dissertation and article.

\section{CONFLICTS OF INTEREST}

The authors declare no conflicts of interest.

\section{ADDRESS FOR CORRESPONDENCE}

109 North, Avenue NS 15, ALCNO 14, Block UMA / UFT, CEP 77.001-090, Palmas, Tocantins, Brazil. 